\title{
In vitro evaluation of canine spermatozoa cryopreserved in different extenders
}

\author{
[Avaliação in vitro do sêmen canino criopreservado em diferentes diluidores de congelação] \\ E.C.S. Oliveira, G.C. Juliani, A.P. Marques Jr., ${ }^{*}$ M. Henry \\ Escola de Veterinária - UFMG \\ Caixa Postal 567 \\ 30123-970 - Belo Horizonte, MG
}

\begin{abstract}
The efficacy of three extenders, tris-egg yolk-5\% ethylene glycol (T1), lactose-egg yolk-5\% ethylene glycol (T2) and lactose-egg yolk-5\% dimethyl formamide (T3) on preserving the viability of postthawing canine spermatozoa was evaluated. Three ejaculates per dog were obtained of five animals. The semen was packaged in $0.5 \mathrm{ml}$ straws and cooled to $4^{\circ} \mathrm{C}$ for $120 \mathrm{~min}$. The straws were frozen $4 \mathrm{~cm}$ above the nitrogen level for $15 \mathrm{~min}$ and thawed in water-bath at $37^{\circ} \mathrm{C}$ for $60 \mathrm{sec}$ and at $75^{\circ} \mathrm{C}$ for $7 \mathrm{sec}$. Progressive motility and vigour were evaluated immediately after thawing (time 0 ) and at 30, 60, 90 and $120 \mathrm{~min}$. Structural and functional integrity of plasma membrane of the spermatozoa were evaluated, respectively, by fluorescent staining probes and hypoosmotic swelling test. Lactose-egg yolk based extenders showed better cryoprotectant capability and dimethyl formamide was an alternative cryoprotectant agent for dog sperm cells.
\end{abstract}

Keywords: dog, semen, cryopreservation, ethylene glycol, dimethyl formamide

\section{RESUMO}

Avaliou-se a eficácia de três diluidores, tris-gema com 5\% de etileno glycol (T1), lactose-gema com 5\% de etileno glicol (T2) e lactose-gema com 5\% de dimetil-formamida (T3) na criopreservação do sêmen de cães. Foram obtidos três ejaculados por cão de um total de cinco animais. O sêmen foi envasado em palhetas de $0,5 \mathrm{ml}$ e resfriado até $4^{\circ} \mathrm{C}$ por $120 \mathrm{~min}$. As palhetas foram congeladas $4 \mathrm{~cm}$ acima do nitrogênio líquido por 15 min e descongeladas em banho-maria a $37^{\circ} \mathrm{C}$ por $60 \mathrm{seg}$ e $75^{\circ} \mathrm{C}$ por $7 \mathrm{seg}$. A motilidade progressiva e o vigor foram avaliados imediatamente após a descongelação (tempo 0) e aos 30, 60, 90 e 120min. A integridade estrutural e funcional da membrana plasmática do espermatozóide foi avaliada, respectivamente, por meio da coloração de fluorescência e pelo teste hiposmótico. Os diluidores à base de lactose gema foram mais eficazes em preservar a viabilidade espermática pósdescongelação e a dimetil-formamida é um crioprotetor eficaz para espermatozóides de cães.

Palavras-chave: cão, sêmen, criopreservação, etileno glicol, dimetil-formamida

\section{INTRODUCTION}

There is an increasing demand for conservation of canine semen among the breeders of valuable dogs. Cryopreservation is an important procedure as it facilitates a wide use of ejaculates of stud dogs, regardless of time and location.

The success of the preservation of spermatozoa by cooling, freezing and thawing is dependent

Recebido em 2 de junho de 2005

Aceito em 28 de julho de 2006

*Autor para correspondência (corresponding author)

E-mail: ampinho@vet.ufmg.br

Apoio: CNPq/FAPEMIG 
upon a series of steps aimed at reducing damage to the cell and securing adequate longevity in vitro and in vivo (Fastad, 1996). Many protocols have been described for canine semen cryopreservation, and differences are linked to cooling rates and equilibration time (Strom et al., 1997; Peña and Linde-Forsberg, 2000) composition of the extenders (Peña et al., 2003) and nature of the cryoprotectants (Olar et al., 1989).

Most of the recent researches have used glycineegg yolk, skimmed milk, lactose-egg yolk (Olar et al., 1989) and tris-egg yolk (Peña and LindeForsberg, 2000; Peña et al., 2003). Also, several companies have developed their own buffers (Silva and Verstegen, 1995; Nothling et al., 1995; Strom et al., 1997).

Glycerol is the most widely cryoprotectant agent used for freezing canine spermatozoa. However, the toxicity of glycerol (Fary, 1986; England, 1993) is leading to the need to elect other alternatives. Penetrating cryprotectants such as dimethyl sulphoxido (DMSO) (Olar, 1989) and ethylene glycol (Vannucchi et al., 1999) have been used for canine sperm preservation. Recent studies used some forms of amides, including methyl and dimethyl formamide (DMF) and acetamide as cryoagent for equine spermatozoa preservation (Hanada and Nagase, 1980; Snoek, 2003; Squires et al., 2004). No reports were found indicating the use of amides on cryopreservation of canine spermatozoa.

Cryopreservation of canine sperm with the available techniques still reduces substantially the survival of spermatozoa in the bitch's genital tract from seven days (Doak et al., 1967) to $12 \mathrm{~h}$ or less (Concannon and Battista, 1989), which is particularly critical in this species due to the long period of heat and receptivity. The high individual variability of the quality of postthawed semen and the short lifespan of thawed spermatozoa in vitro indicate that the current cryopreservation methods are not optimal, which may partially account for reduced conception rates obtained after artificial insemination (AI) with frozen semen (Peña et al., 2003).

The aim of this study was to study the efficacy of three extenders on preserving the viability of post-thawing canine spermatozoa.

\section{MATERIALS AND METHODS}

Five dogs were used being two Shar-Pei, one Retriever of Labrador, one Basset-Hound and one crossbred, 2 to 8 year-old. After extragonadal reserve sperm renewal, three ejaculates per dog were obtained with an interval of $72 \mathrm{~h}$. Immediately post-collection, seminal analysis included concentration and sperm progressive motility (PM), vigour (V) and morphology. Only ejaculates showing $\geq 80 \%$ $\mathrm{PM}$, vigour $\geq 4$ and $\geq 70 \%$ of morphologically normal sperm cells were included in the study.

Semen was initially diluted 1:1 in glucose-EDTA extender (Martin et al., 1979), divided into three aliquots and centrifuged at $655 \mathrm{~g}$ for $6 \mathrm{~min}$. The supernatant was discarded and each sperm pellet was diluted in one of the three freezing extenders (Table 1). The extenders were: tris-egg yolk-5\% ethylene glycol (T1), lactose-egg yolk-5\% ethylene glycol (T2) and lactose-egg yolk-5\% dimethyl formamide (T3). Final dilution was performed in order to obtain $100 \times 10^{6}$ spermatozoa $/ \mathrm{ml}$. Samples were packaged in $0.5 \mathrm{ml}$ straws and placed in a refrigerated styrofoam box to cool down to $5^{\circ} \mathrm{C}$ in 60 minutes; additional 60 minutes at $5^{\circ} \mathrm{C}$ completed equilibration time. Straws were frozen $4 \mathrm{~cm}$ above the surface of liquid nitrogen $\left(\mathrm{LN}_{2}\right)$ for 15min (Bueno, 2000).

The thawing regimens were: $37^{\circ} \mathrm{C}$ for $1 \mathrm{~min}$ (Silva et al., 1998) and $75^{\circ} \mathrm{C}$ for $7 \mathrm{sec}$ followed by a minimum of $1 \mathrm{~min}$ in $37^{\circ} \mathrm{C}$ water-bath (Strom Holst et al., 2000). A $200 \mu \mathrm{l}$ aliquot of thawed semen was placed in a $1.5 \mathrm{ml}$ plastic tube and incubated at $37^{\circ} \mathrm{C}$. Sperm PM and V were evaluated immediately after thawing (time 0 ) and at 30,60, 90 and $120 \mathrm{~min}$.

Functional integrity of sperm membrane of the tail was assessed immediately after thawing by the hypo-osmotic swelling test (HOS-test) (KumiDiaka, 1993) using a 60-mosmol fructose solution. Samples were processed according to Jeyendran et al. (1984). Two hundreds cells were counted at 1000X magnification and the percentage of curling/swelling tails was determined according to Melo and Henry (1999).

Structural integrity of sperm head membranes was assessed immediately after thawing using 
6-carboxifluorescein diacetate (C-FDA) and propide iodide (PI) (Harrison and Vickers, 1990). Hundred sperm cells per sample were counted at 400X magnification. Cells were classified as intact
- showing green fluorescence of the C-FDA due to plasma and acrosomal membranes integrity, and damaged - showing red fluorescent of the PI due to damaged plasma and acrosomal membranes.

Table 1. Composition of freezing extenders used for canine semen cryopreservation

\begin{tabular}{lccc}
\hline & Tris5\%EG(T1) & Lac5\%EG $^{*}(\mathrm{~T} 2)$ & Lac5\%DMF $^{*}(\mathrm{~T} 3)$ \\
\hline Tris & $3.025 \mathrm{~g}$ & - & - \\
Citric acid, monohydrate & $1.7 \mathrm{~g}$ & - & - \\
Fructose & $1.25 \mathrm{~g}$ & - & - \\
Lactose 11\% & - & $50 \mathrm{ml}$ & $50 \mathrm{ml}$ \\
Glucose-EDTA & - & $25 \mathrm{ml}$ & $25 \mathrm{ml}$ \\
Egg yolk & $20 \mathrm{ml}$ & $20 \mathrm{ml}$ & $20 \mathrm{ml}$ \\
Ethylene glycol & $5 \mathrm{ml}$ & $5 \mathrm{ml}$ & $5 \mathrm{ml}$ \\
Dimethyl formamide & - & - & - \\
Streptomycin sulphate & $0.10 \mathrm{~g}$ & - & $0.5 \mathrm{ml}$ \\
Equex STM Paste & - & $0.5 \mathrm{ml}$ & - \\
Distilled water & to $100 \mathrm{ml}$ & - & 6.97 \\
\hline pH & 6.86 & 6.91 & 1289 \\
Osmolarity & 1220 & 1365 & \\
\hline
\end{tabular}

*Martin et al. (1979) modified

${ }^{* *}$ Nova Chemical Sales, Scituate, Inc., MA, USA.

Results are presented as means and standard deviation. Analysis of variance was used to evaluate differences between extenders and the effect of thawing regimens. Means obtained for different parameters (progressive motility and integrity of sperm membranes) were compared by the Students't test $(\mathrm{P}<0.05)$, while vigour was analyzed by Kruskall-Wallis test (Sampaio, 1998). All analyses were performed using the Statistical Package for Social Science Program (Statistical...,1999).

An independent two-sample t-test was used to compare results of the thermalresistance test. For dependent samples, it was used the paired $\mathrm{t}$ command. The commercial software Minitab version 13 was used for this analysis.

\section{RESULTS}

Parameters of post-thawed sperm cells are shown in Table 2. Immediately post-thawing, the effect of thawing regimen within extenders was observed only for PM in T2 and for HOS in T1. Significantly higher PM in T2 and lower HOS response in T1 samples were observed when both were thawed at $37^{\circ} \mathrm{C}(\mathrm{P}<0.05)$.

Table 2. Parameters of sperm cells of immediately post-thawed dog semen cryopreserved in three extenders and thawed at two temperatures

\begin{tabular}{cccccc}
\hline Freezing extender & TR & PM(\%) & NOR(\%) & INT(\%) & HOS $(\%)$ \\
\hline Tris5\%EG (T1) & 1 & $34.8 \pm 7.4 \mathrm{bA}$ & $84.4 \pm 8.9 \mathrm{aA}$ & $49.7 \pm 4.7 \mathrm{bA}$ & $55.5 \pm 7.0 \mathrm{aB}$ \\
& 2 & $28.7 \pm 6.6 \mathrm{bA}$ & $88.4 \pm 7.0 \mathrm{aA}$ & $52.5 \pm 8.7 \mathrm{bA}$ & $62.4 \pm 8.6 \mathrm{aA}$ \\
Lac5\%EG (T2) & 1 & $37.7 \pm 8.4 \mathrm{abA}$ & $78.0 \pm 5.2 \mathrm{aA}$ & $67.6 \pm 4.1 \mathrm{aA}$ & $58.8 \pm 7.8 \mathrm{aA}$ \\
& 2 & $28.5 \pm 10.4 \mathrm{bB}$ & $75.6 \pm 6.9 \mathrm{bA}$ & $70.8 \pm 7.2 \mathrm{aA}$ & $65.0 \pm 9.6 \mathrm{aA}$ \\
Lac5\%DMF (T3) & 1 & $45.5 \pm 11.3 \mathrm{aA}$ & $65.3 \pm 14.2 \mathrm{aA}$ & $56.7 \pm 7.5 \mathrm{bA}$ & $49.2 \pm 6.6 \mathrm{aA}$ \\
& 2 & $43.3 \pm 6.4 \mathrm{aA}$ & $69.5 \pm 11.2 \mathrm{bA}$ & $56.5 \pm 5.3 \mathrm{bA}$ & $51.2 \pm 7.9 \mathrm{bA}$ \\
\hline
\end{tabular}

$\mathrm{PM}=$ progressive motility; NOR=morphologically normal spermatozoa; $\mathrm{INT}=$ normal structural integrity of plasma and acrossomal membranes; HOS=functional integrity of plasma membrane; TR = thawing regimen: 1 $37^{\circ} \mathrm{C}$ for $1 \mathrm{~min} ; 2-75^{\circ} \mathrm{C}$ for $7 \mathrm{sec}$ followed by a minimum of $1 \mathrm{~min}$ in $37^{\circ} \mathrm{C}$ water-bath. Lac=lactose; $\mathrm{EG}=$ ethylene glycol; $\mathrm{DMF}=$ dimethyl formamide

Means with different capital letters between TR and different lower case letters between freezing extenders differ, $\mathrm{P}<0.05$ (Student $\mathrm{t}$-test). 
Samples thawed at $37^{\circ} \mathrm{C}$ showed lower PM in T1 compared to $\mathrm{T} 3(\mathrm{P}<0.05)$; higher proportion of sperm with normal structure of plasmatic and acrosomal membranes was found in $\mathrm{T} 2(\mathrm{P}<0.05)$ and no effect was observed for the HOS response. Using $75^{\circ} \mathrm{C}$ as thawing temperature, $\mathrm{PM}$ was higher in $\mathrm{T} 3(\mathrm{P}<0.05)$, higher normal sperm morphology was found in $\mathrm{T} 1$, higher proportion of sperm cells had normal structure of the plasmatic and acrosomal membranes in T2 $(\mathrm{P}<0.05)$ and lower proportion of sperm cells reacted to the HOS in T3 $(\mathrm{P}<0.05)$.

PM values during incubation at $37^{\circ} \mathrm{C}$ are shown in Table 3. Drop of PM was faster in samples frozen in $\mathrm{T} 1$ when samples were thawed at $37^{\circ} \mathrm{C}$ $(\mathrm{P}<0.05)$. A similar trend was observed when thawing temperature was $75^{\circ} \mathrm{C}$.

Table 3. Percentage of progressively motile spermatozoa during incubation at $37^{\circ} \mathrm{C}$ of canine semen cryopreserved in three extenders and thawed at two temperatures

\begin{tabular}{|c|c|c|c|c|c|}
\hline \multirow{2}{*}{$\begin{array}{l}\text { Thawing rate: } \\
37^{\circ} \mathrm{C} \text { for } 1 \mathrm{~min} \\
\text { Freezing extender }\end{array}$} & & Incubation & \multicolumn{2}{|l|}{ time(min) } & \\
\hline & 0 & 30 & 60 & 90 & 120 \\
\hline Tris5\%EG (T1) & $34.8 \pm 7.4 \mathrm{~b}$ & $11.82 \pm 5.08 \mathrm{~b}$ & $3.32 \pm 4.25 b$ & $1.32 \pm 2.17 \mathrm{~b}$ & $0 \mathrm{~b}$ \\
\hline Lac5\%EG (T2) & $37.3 \pm 8.4 \mathrm{ab}$ & $20.66 \pm 5.21 \mathrm{a}$ & $15.98 \pm 7.51 \mathrm{a}$ & $7.98 \pm 5.07 \mathrm{a}$ & $2.88 \pm 2.83 \mathrm{a}$ \\
\hline Lac5\%DMF (T3) & $45.5 \pm 11.3 \mathrm{a}$ & $21.16 \pm 5.09 \mathrm{a}$ & $10.98 \pm 6.31 \mathrm{a}$ & $5.3 \pm 3.63 \mathrm{a}$ & $3.78 \pm 3.0 \mathrm{a}$ \\
\hline \multirow{2}{*}{$\begin{array}{l}\text { Thawing rate: } \\
75^{\circ} \mathrm{C} \text { for } 7 \mathrm{sec} \\
\text { Freezing extender }\end{array}$} & & Incubation & time(min) & & \\
\hline & 0 & 30 & 60 & 90 & 120 \\
\hline Tris5\%EG (T1) & $28.7 \pm 6.6 b$ & $10.87 \pm 6.37 \mathrm{~b}$ & $5.66 \pm 6.62 b$ & $3.64 \pm 4.46 b$ & $1.66 \pm 2.35 b$ \\
\hline Lac5\%EG (T2) & $28.5 \pm 10.4 b$ & $19.1 \pm 9.39 \mathrm{ab}$ & $12.64 \pm 7.4 \mathrm{ab}$ & $10.32 \pm 8.09 \mathrm{ab}$ & $3.98 \pm 3.25 \mathrm{a}$ \\
\hline Lac5\%DMF (T3) & $43.3 \pm 6.4 a$ & $27.76 \pm 10.90 \mathrm{a}$ & $19.94 \pm 9.32 \mathrm{a}$ & $13.32 \pm 6.78 \mathrm{a}$ & $7.32 \pm 4.34 \mathrm{a}$ \\
\hline
\end{tabular}

$\mathrm{Lac}=$ lactose $; \mathrm{EG}=$ ethylene glycol; $\mathrm{DMF}=$ dimethyl formamide.

Column values with different letters differ $(\mathrm{P}<0.05)$ for freezing extenders.

\section{DISCUSSION}

The use of several in vitro tests showed that each extender had different capability of sperm preservation depending on the evaluated parameter and they were not similarly better or worst for a given extender. Sperm motility immediately post-thawing was higher in semen diluted in T3, a higher percentage of morphologically normal sperm cells was found in $\mathrm{T} 1$, the percentage of sperm cell maintaining the integrity of the plasma and acrosome membranes was higher in $\mathrm{T} 2$, while lower percentage of cells reacted to the hipoosmotic test in $\mathrm{T} 3$ when thawed at $75^{\circ} \mathrm{C}$. Also, the integrity of the plasmatic and acrosomal membranes and functional integrity of the tail membrane seemed to be, immediately after thawing, better preserved than the motility. In other studies, low correlation were found between these parameters of sperm cells postthawing (Snoeck, 2003). Better HOS-test response than motility after thaw has also been observed in equine spermatozoa (Neild et al., 1999). According to Melo and Henry (1999), it is possible to find spermatozoa with functional plasma membrane integrity, but without motility. These spermatozoa could maintain the potential to acquire motility inside the female reproductive tract. This fact is supported by the statements of Silva and Verstegen (1995), who tested the efficacy of three extenders using artificial insemination and showed higher fertility index for samples that presented the lowest percentage of motility after thawing. In the present study, the results demonstrate that, when thawed at $75^{\circ} \mathrm{C}$, T3 showed the lowest number of spermatozoa with functional plasma membrane integrity when compared to the other two treatments, despite the higher progressive motility post-thawing. It is imperative, in order to adequately rank the cryoprotectant potential of extenders, to study the correlation between each evaluated parameter and fertility. It would be interesting to know if functional and/or structural integrity of the plasma membrane immediately 
after thawing have a higher correlation than motility with the fertilizing capacity of dog spermatozoa. Considering the four parameters together, immediately post-thawing, it is not evident which extender has a better cryoprotectant potential.

A discrete interaction between extenders and thawing rate could be observed in the present study. Lower $(\mathrm{P}<0.05)$ post-thawing motility was observed in $\mathrm{T} 2$ and higher $(\mathrm{P}<0.05)$ percentage of sperm cell reacting to the HOS-test was observed in $\mathrm{T} 1$ extender when the samples were thawed at $75^{\circ} \mathrm{C}$ as compared to $37^{\circ} \mathrm{C}$. Other parameters for all three extenders did not vary according to thawing temperature. This indicates that efficiency of post-thawing cell survival for a given extender may be improved if thawing temperature is adjusted.

Considering the thermalresistance test, it can be seen that lactose based extenders, independently of the cryoagent used, showed better sperm longevity than the TRIS extender using ethylene glycol as cryoagent. This was particularly seen when samples were thawed at $37^{\circ} \mathrm{C}$. Using $75^{\circ} \mathrm{C}$, $\mathrm{T} 3$ also showed a better performance than $\mathrm{T} 1$, while post-thawed longevity of sperm cells frozen in T2 showed intermediate values. Better longevity performance of lactose based extenders may reflect, in one side, an initial better post-thawing motility (T3) and, on the other side, a better protection of sperm membranes (T2). These results indicate that the use of several parameters to evaluate postthawing sperm cells in vitro may help in predicting viability. As far as longevity is concerned it seemed that sperm morphology (T1) had low predicting value. Molinia et al. (1994) suggested that extenders with superior motility immediately after thawing were likely to sustain the motile cell population longer, while those with lower motility were likely to have a higher incidence of cell mortality. However, Strom et al. (1997) suggested that a higher initial motility leads to a quicker consumption and depletion of ATP and increase in metabolic waste products, which could contribute to a quicker decrease in motility. The results of the present study indicate that spermatozoa with a high initial motility do not necessarily have a low longevity, since a longer longevity was found when T3 was used, which showed the best PM immediately postthawing.

Several compounds varied between $\mathrm{T} 1$ and T2/T3 extenders. In previous studies Peña and Linde-Forsberg (2000) and Peña et al. (2003) showed a beneficial effect of the addition of Equex STM paste to Tris-egg yolk freezing extender.

The active compound in Equex STM paste is the sodium dodecyl sulphate (SDS), a water-soluble, anionic detergent that probably exerts its action by reducing lipid phase transitions and/or protecting the function of membranes by controlling the calcium influx (Strom Holst et al., 2000; Peña et al., 2003).

Ethylene diamine tetra-acetate (EDTA) was also present in the lactose-egg yolk based extenders (T2 and T3), but not in the Tris-egg yolk (T1). EDTA acts as a chelator limiting the movement of divalent ions across the plasma membrane by binding calcium and magnesium resulting in lower intracellular calcium concentrations (Graham, 1996). It prevents or delays the progress of capacitation-like changes in thawed spermatozoa, prolonging their post-thawing longevity (Pena et al., 2003),

The integrity of plasma membrane of spermatozoa is essential for cell viability, as its selective permeability maintains intracellular metabolic activities, $\mathrm{pH}$ and ionic composition (Strom et al., 1997). An important way in which a cryoprotectant stabilizes cells during freezing involves interactions between cryoprotectant and cell membranes (Strom Holst et al., 2000). Limited studies are available on the use of ethylene glycol (EG) as a cryoprotectant for freezing canine semen. Vanucchi et al. (2002) reported a progressive motility of $62.9 \%$ for frozen semen using 5\% EG as a cryoprotectant. Soares et al. (2002) obtained similar results with semen which was frozen in extenders containing 0.25 or $0.5 \mathrm{M}$ of EG. These data showed that T2 preserved better the structural integrity of the plasma membrane than the two other treatments. The association of lactose-egg yolk extender with a cryoprotectant of low toxicity as EG, which has high permeability due to its low molecular weight (Vannucchi, 1999) is likely to better stabilize the structure of the plasma 
membranes. Based on the results of the present study and preliminary data from two above mentioned studies, a larger trial using EG as the cryoprotectant should be conduct.

There is a lack of information concerning the effects of amides as cryoprotectants for freezing canine semen. Studies in other species showed that amides and particularly DMF showed a cryoprotectant effect on sperm cells ( Hanada and Nagase, 1980; Alvarenga et al., 2000; Medeiros et al., 2002; Squires et al., 2004). In the present study, 5\% DMF extender showed a better capacity of preserving motility postthawing compared to the other two extenders. On the other hand, it is not known whether the lower capability of DMF to preserve the integrity of plasma membranes of spermatozoa when compared to the ethylene glycol (T2) is related to the concentration used or to a more effective protective effect of the membranes by the ethylene glycol. The 5\% DMF concentration used in this study was chosen because most extenders currently using DMF as cryoagent for semen in other species contain a concentration varying between $2 \%$ to $6 \%$ (Hanada and Nagase, 1980; Squires et al., 2004 ).

Due to differences in the composition between $\mathrm{T} 1$ and $\mathrm{T} 2 / \mathrm{T} 3$ extenders, it makes difficult, to identify which compound or association of compounds could have brought improvements as shown using T2 and T3 extenders.

It can be concluded that the association of lactose-egg yolk with 5\% EG (T2) and lactoseegg yolk with 5\% DMF (T3) improves the postthawing viability of dog semen when compared with tris-egg yolk 5\% EG (T1). It has also been demonstrated that the cryoprotectant agent DMF is an alternative cryoagent for canine semen cryopreservation.

\section{REFERENCES}

ALVARENGA, M.A.; GRAHAM, J.K.; LANDIM-ALVARENGA, F.C. et al. Alternatives cryoprotectors for freezing stallion semen. In: INTERNATIONAL CONFERENCE ON ANIMAL REPRODUCTION, 11., 2000. Proceeding ... Stockholm, Sweden, 2000. p.93
BUENO, R. Criopreservação de sêmen canino utilizando dois diluidores e dois protocolos de resfriamento. 2000. 91f. Dissertação (Mestrado em Medicina Veterinária) - Departamento de Medicina Veterinária, Universidade Federal de Viçosa, Viçosa.

CONCANNON, P.W.; BATTISTA, M. Canine semen freezing and artificial insemination. In: KIRK, R.W. (Ed.). Current veterinary therapy. Philadelphia: W.B. Saunders, 1989. p.12471259.

DOAK, R.L.; HALL, A.; DALE, H.E. Longevity of spermatozoa in the reproductive tract of the bitch. J. Reprod. Fertil., v.13, p.51-58, 1967.

ENGLAND, G.C.W. Cryopreservation of dog semen: a review. J. Reprod. Fertil., v.47, p.243255, 1993.

FARY, G.M. The relevance of cryoprotectant oxicity to cryobiology. Cryobiology, v.23, p.113, 1986.

FASTAD, W. Semen cryopreservation in dog and foxes. Anim. Reprod. Sci., v.12, p.145-150, 1996.

GRAHAM, J.K. Cryopreservation of stallion spermatozoa. Vet. Clin. N. Am.: Equine Pract., v.12, p.131-147, 1996.

HANADA, A.; NAGASE, H. Cryoprotective effects of some amides on rabbit spermatozoa. $J$. Reprod. Fertil., v.60, p.247-252, 1980.

HARRISON, R.A.P.; VICKERS, S. Use of fluorescent probes to assess membrane integrity im mammalian spermatozoa. J. Reprod. Fertil., v.88, p.343-352, 1990.

JEYENDRAN, R.S.; VAN DER VEM, H.H.; PEREZ, M. et al. Development of an assay to assess the functional integrity of the humam sperm membrane and its relationship to other semen characteristics. J. Reprod. Fertil., v.47, p.219-228, 1984.

KUMI-DIAKA, J. Subjecting canine semen to hypo-osmotic test. Theriogenology, v.39, p.1279-1289, 1993.

MARTIN, J.C.; KLUG, E.; GUNZELA, A.R. Centrifugation of stallion semen and its storage in large volume straws. J. Reprod. Fertil., v.27, p.47-51, 1979. 
MELO, M.I.V.; HENRY, M. Teste hiposmótico na avaliação do sêmen equino. Arq. Bras. Med. Vet. Zootec., v.51, p.71-78, 1999.

MOLINIA, F.C.; EVANS, G.; MAXWELL, W.M.C. In vitro evaluation of zwitterion buffers in diluents for freezing ram spermatozoa. Reprod. Nutr. Dev., v.34, p.491-500, 1994.

NEILD, D.; CHAVES, G.; FLORES, M. et al. Hypoosmotic test in equine spermatozoa. Theriogenology, v.51, p.721-727, 1999.

NOTHLING， J.O.; GERSTENBERG， C.; VOLKMANN, D.H. Success with intravaginal insemination of frozen-thawed $\operatorname{dog}$ semen - a retrospective study. J. S. Afr. Vet Assoc., v.66, p.49-55, 1995.

OLAR, T.T.; BOWEN, R.A.; PICKETT, B.W. Influence of extender, cryopreservative and seminal processing procedures on posthaw motility of canine spermatozoa frozen in straws. Theriogenology, v.31, p.451-461, 1989.'

PENÃ, A.; LINDE-FORSBERG, C. Effects of Equex, one or two step dilution, and two freezing and thawing rates on post-thaw survival of dog spermatozoa. Theriogenology, v.54, p.859-875, 2000.

PEÑA, A.I.; LÓPEZ-LUGILDE, L.; BARRIO, M. et al. Studies on the intracellular $\mathrm{Ca}^{2+}$ concentration of frozen-thawed do spermatozoa: influence of Equex from different sources, two thawing diluents and post-thaw incubation in capacitating conditions. Reprod. Dom. Anim., v.38, p.27-35, 2003.

SILVA, L.D.M.; VERSTEGEN, J.P. Comparisons between three differents extenders for canine intrauterine insemination with frozenthawed spermatozoa. Theriogenology, v.44, p.571-579, 1995.
SQUIRES, E.L.; KEITH, S.L.; GRAHAM, J.K. Evaluation of alternative cryoprotectants for preserving stallion spermatozoa. Theriogenology, v.62, p.1056-1065, 2004.

VANNUCCHI, C.F.; SANTOS, S.E.C.; VISINTIN, J.A. In vitro viability of canine spermatozoa frozen in tris-fructose-citric acid extender with ethylene glycol. Braz. J. Vet. Res., v.36, p.205-211, 1999.

SNOECK, P.P.N. Aspectos da criopreservação de sêmen eqüino: composição do meio diluidor, curvas de congelamento e fertilidade. 2003. 116f. Tese (Doutorado em Ciência Animal) Escola de Veterinária, Universidade Federal de Minas Gerais, Belo Horizonte.

SAMPAIO, I.B.M. Estatística aplicada à experimentação animal. Belo Horizonte: FEPMVZ, 1998. 221p.

SILVA, A.R.; CARDOSO, R.C.S.; SILVA, L.D.M. Efeito do processo de descongelação sobre a viabilidade do sêmen canino in vitro. Cien Anim., v.8, p.75-80, 1998.

SOARES, M.P.; ROSSI, C.A.R.; MEZZALIRA, A. et al. Etilenoglicol na criopreservação de semen canino. Cien. Rural, v.32, p.649-655, 2002.

STATISTICAL PACKAGE for the Social Sciences. Base 10.0 User's Guide. Chicago: SPSS, 1999.

STROM , B.; ROTA, A.; LINDE-FORSBERG, C. In vitro characteristics of canine spermatozoa subjected to two methods of cryopreservation. Theriogenology, v.48, p.247-256, 1997.

STROM HOLST, B.; LARSSON, B.; LINDEFORSBERG, C. et al. Evaluation of chilled and frozen-thawed canine spermatozoa using a zona pellucida binding assay. J. Reprod. Fertil., v.119, p.201-206, 2000. 